\title{
"Antibureaucratism" as a Yugoslav Phenomenon: The View from Northwest Croatia
}

\author{
Rory Archer* \\ Department of History and Sociology, University of Konstanz, Konstanz, Germany \\ ${ }^{\star}$ Corresponding author. Email: Rory.Archer@uni-konstanz.de
}

\begin{abstract}
Most studies of the antibureaucratic revolution have focused on political elites and activists in Serbia, Montenegro, and the autonomous provinces of Vojvodina and Kosovo. Recent scholarship has focused on individual participants, often workers, and takes their agency seriously. Building upon such research, this article explores the antibureaucratic revolution as a particular manifestation of a larger sociocultural process, constitutive of long-term structural changes across the whole of Yugoslavia. An analysis of workplace documents and local newspapers in northwest Croatia demonstrates that antibureaucratic sentiment was not the prerogative of Serbian and Montenegrins but of Yugoslav citizens more generally. Yugoslavs were conditioned by the party-state to be critical of bureaucracy. Workers began to admonish the expansion of administrative positions, which they blamed for their falling living standards. Despite decentralizing and autarkic tendencies in political and economic life in late socialist Yugoslavia, working class discontents (and representations of it) remained remarkably similar across republican boundaries. In Rijeka and its environs, a shift does not occur until in mid-1988. Condemnations of nationalism become more urgent and a skepticism toward the mass protests occurring in Serbia is palpable from this point onward.
\end{abstract}

Keywords: Yugoslavia; labor history; antibureaucratic revolution; late socialism; Rijeka

\section{Introduction}

In September 1987, a blue-collar worker wrote and published a scathing article in which he portrayed a situation where white-collar workers were abusing their position at the expense of other workers. This was published in his workplace periodical (at the time, most larger Yugoslav companies published such semi-internal documents). While much content would be devoted to the economic performance of the company or developments in the particular industrial sector, it was also common for discussions to take place on issues of social concern-on housing provision, leisure activities, political participation, sport, public health, and the living standard of workers. The factory press usually provided space for both workers and management to voice opinions on issues of concern. ${ }^{1}$ Workers would often contribute to such publications by sending in letters, jokes, poems and cartoons; they were also interviewed on topical issues. In the spirit of Yugoslav socialist reflexivity, the viewpoints put forward were quite varied. The publications represented a site of mediation where a diversity of perspectives and competing interests could be expressed. 
The particular contribution, titled "A Crisis of Behavior," was harsher than most, though reflective of an ever more conflict-ridden Yugoslav society in which worker discontent was finding expression in increasing strike activity during the second half of the 1980s (Fočo 1989). The author writes caustically:

How should I behave when the bureaucrat decides my fate [kroji kapu] ... How should I behave when at the meeting they almost never let me speak? How should I behave when I have to work on Sundays and public holidays but THEY already on Friday start their weekend and on Monday return refreshed? How should I behave when I have to wait twenty years for a flat but THEY only two? How should I behave when I have no connections or cronies but THEY have them, and are free to call upon them by phone? How should I behave when, during the working day, they go to a café and to a hotel for a "drink" but of course, I can't? How should I behave while they drink coffee and I wait for them to validate my health insurance? ... How should I behave when delegates, representatives, bosses and everyone else, they tell me: That is all self-management, for all those rulebooks, deals and agreements you have voted! "We told you, we explained to you, you understood it all." Yes comrade, Self-managing comrade!

And so I get that I act "selfmanagingly" [samoupravno] ...

And I decided that I should work:

as easy as possible,

as little as possible,

as short as possible

... because that is how they work, but they receive a decent wage. ${ }^{2}$

It might seem that the irate voice of this worker most probably originated in an industrial center in Serbia, or perhaps Montenegro. The next summer industrial workers would be instrumental in toppling workplace, municipal and provincial leadership in Vojvodina and Montenegro and participating in protests across Serbia, consolidating the position of Slobodan Milošević in the process. The worker's complaint might then be read as a harbinger of the militant mass movement that was soon to follow-indeed the first target of the worker in his diatribe is the "bureaucrat" and the entire text follows the populist dichotomy of "us and them."

Yet this text did not originate from Serbia. It was published in the periodical of Jugolinija, a large shipping firm in Rijeka, in northwest Croatia. The author is credited as Branislav Kostić, who presumably is a blue-collar worker. While Kostić may well have identified as Serb-Rijeka was a multiethnic industrial center and a bastion of "Brotherhood and unity" with a strong presence of Serbs, Slovenes, Italians, and other minorities (Abram 2018, 72-77; Rutar 2015, 277-278) -the targets of his complaints were Jugolinija workers based in Rijeka. The article was published under a regular section for workers' contributions called "Questions without Answers" suggesting the ideas in the section were rhetorical questions already in public circulation. From reading Kostićs September 1987 text as well as previous content in Jugolinija documents and those of nearby shipping firm Jadrolinija, Rijeka Port (RO "Luka"), and the Pula-based shipbuilding company Uljanik, one can ascertain that many of the grievances that would find expression in Serbia and Montenegro a year later were also very palpable among blue-collar workers in Croatian coastal cities.

This article explores the context of the antibureaucratic revolution, the so-called happening of the people that swept across Serbia and Montenegro in 1988 and 1989, by interrogating how conditions in late socialist Yugoslavia lent themselves to the production of populist representations among workers. Rather than focusing on the militant Kosovo Serb activists and protesting workers of "frontline" towns and neighborhoods like Titov Vrbas and Bačka Palanka in Vojvodina; Rakovica and Zemun in Belgrade; or Nikšić and Titograd in Montenegro (on this, see Grdešić, this volume; Musić 2016; Lekić, Pavić, and Lekić 2009; Vladisavljević 2008), I focus on coastal cities in northwestern Croatia like Rijeka that were not directly involved in the antibureaucratic revolution.

Concentrating on the derision of bureaucracy in late socialist Croatia serves to highlight pan-Yugoslav elements of an ideological, cultural, and discursive phenomenon that would culminate 
in the antibureaucratic revolution in Serbia and Montenegro in 1988 and 1989. I make the argument that despite increased autarky, uneven development and decentralizing impulses across Yugoslav republics, many of the fundamental discontents with regard to "worlds of work" were comparable and coherent across the federation. Thus, when one examines representations of work, dissatisfaction in the workplace, and issues of discontent for working-class communities in Prizren or Pula, in Rakovica or Rijeka, in Lapovo or Labin, the tropes are remarkably similar. Workers were concerned about declining living standards; growing divisions between blue-collar and white-collar workers; the proliferation of bureaucracy, careerism, corruption, and the theft of social property; and a crisis of labor and work ethic evident in the increase in shirking [nerad], absenteeism, and sick leave.

This article first identifies particular features of the Yugoslav system that rendered the party-state amenable to "antibureaucratic" expressions of worker discontent-namely, self-managing socialism identified the state bureaucracy as the enemy of working people and so legitimized antibureaucratic discourse. The objective expansion of the bureaucracy in the 1970s following the restructuring of the economy along Edvard Kardelj's lines gave further impetus to antibureaucratic critique. The relative openness of the Yugoslav system encouraged a degree of criticism within which debates about the widening gaps between theory and practice could take place in an expanding tabloid media market.

Following this discussion, I examine some of the instances of dissatisfaction in northwest Croatian workplaces like Jugolinija. I argue that these were rather similar to the dominant themes in circulation among workers in Serbia and Montenegro in the years prior to the antibureaucratic revolution. Although all Yugoslav workers continued to be formally invested with symbolic capital, precipitously falling living standards contravened the Titoist social contract (Andrejevich 1988b, 21), the "Yugoslav Dream" (Patterson 2011) that was predicated on a continuous rise in living standards and consumption.

Such plummeting living standards and cuts in wages and bonuses because of falling productivity, losses and austerity measures ("economic stabilization") heralded a wave of strikes in the second half of the 1980s. These strikes, while initially concerned with intra-factory dynamics (mainly wage distribution), began to tackle broader societal issues. They targeted not only factory management by protesting in the vicinity of the workplace, but also entered symbolic public spaces from town centers right up to the Federal Parliament of Yugoslavia in Belgrade (Cvek, Ivčić, and Račić 2015; Musić 2016). These high-profile strikes transcended republican borders and made broad socioeconomic, political, and moral claims in the name of Yugoslavia's working class. In Serbia and Montenegro strikes coalesced with a nationalist movement advocating for the rights of Kosovo Serbs, yet the socioeconomic component remained consistently salient, with oscillations taking place between the national and social content of protests (Andrejevich 1988c, 23).

In concluding the article, I address an understudied aspect of the antibureaucratic revolution: its reception in Yugoslavia outside of Serbia and Montenegro. The meetings organized by Kosovo Serb activities and their anti-autonomist allies were attempted in other republics, with the most infamous case being the banned "Meeting of Truth" scheduled in Ljubljana in December 1989 (Sundhaussen 2012, 286-287). Prior to this, however, authorities in Croatia, Bosnia Herzegovina, and Macedonia responded negatively to attempts to organize meetings. Planned events in Jajce, Šipovo, and Sarajevo in September 1988 did not transpire because of the intervention of Bosnia Herzegovina republican and local authorities, and an attempt to hold a meeting in Skopje was similarly cancelled (Andrejevich 1988a, 8). In parts of Croatia with significant Serb populations, like Kninska Krajina and Eastern Slavonia, statements of support and some demonstrations did occur by 1989 (Marijan 2016). In Rijeka and its environs however, the nationalist tone of the protests in Serbia during the summer of 1988 failed to resonate, and the motives of demonstrators began to be called into question.

\section{Bureaucracy in Late Socialist Yugoslavia}

In Yugoslav socialism, the designation of the state bureaucracy as the "main adversary of working-class interests" (Archer and Musić 2017, 47) ensured that the abstract specter of bureaucracy in opposition 
to self-managing socialism would be a frequent and legitimate trope of discussion in public life (Zukin 1975, 210). Birokratizam was considered by Edvard Kardelj in the early 1950s as "the final and most stubborn legacy of the class system and therefore the most dangerous enemy of socialism" (cited in Suvin 2012a, 142; for a detailed discussion of the concept of bureaucracy, see Darko Suvin 2011, 2012a, 2012b; Zukin 1975, 210-212).

In the vocabulary of Yugoslav socialism, bureaucracy [birokracija] was often used alongside other negative markers of anti-socialist behavior such as nationalism, liberalism, techomanagerialism, and perhaps that most negative of terms, counterrevolution (Jović 2009, 8). A 1981 dictionary of self-management terminology defines bureaucracy as both a layer of professional managers and a system of social and political relations in which bureaucrats have the leading role. The even more negative term birokratizam is understood a "set of occurrences which are the result of the actions of bureaucracy; the way in which bureaucracy manifest and affects society" (Sorić 1981, 21). The bureaucracy was an omnipresent if indistinct term of derision in Yugoslav socialism from the inception of the socialist state, and it was a sufficiently flexible empty or floating signifier (Grdešić 2016, 779) to be molded according to the needs of the day. Thus, as Nebojša Vladisavljević (2008, 176) writes, "[ $t]$ he embeddedness of the antibureaucratic theme in Yugoslavia's political and cultural life explains why it resonated so well with its citizens in the autumn of 1988."

Yugoslav reflexive socialism enabled quite a broad degree of public discussion and constructive criticism to occur, albeit within certain parameters and provided it was couched in the appropriate terminology of socialist self-management (Robinson 1977; Ramet 1985b). The bureaucratic theme was a legitimate framework within which to critique the work of officials in the press. The bureaucratic "cruelty" of municipal staff was a ubiquitous topic from at least the late 1970s in a media market that was increasingly commercialized and oriented toward proto-tabloid formats.

Reporting on the problems of the day, however, was not only the preserve of tabloids. Established broadsheets like Borba and Vjesnik also reported more often on human interest stories and controversial issues like "work stoppages" and inefficient municipal bureaucracies. In the fallout of the quelled demonstrations in Kosovo in 1981 the press was "full of revelations on political and economic abuses ... becoming increasingly frank in its criticisms." 3 This was not lost on the Yugoslav party-state, which was frustrated with the "sensationalist and ill-intended [nedobronamerno]" reporting on sensitive issues like instability in Kosovo. ${ }^{4}$ Documents from the mid-1980s also suggest that the upper echelons of the party-state were aware of the growing frustration of ordinary citizens in their dealings with state and municipal officials. ${ }^{5}$ A 1986 report about the political and security situation in Serbia cautioned,

[c]itizens find it hard and loose much time in a labyrinth of procedures and institutions which irritates them and makes them very critical toward the system. In many organs and administrations that citizens are directed toward, a bureaucratic logic rules ... and occurrences that violate the dignity of individuals, working people and citizens (the way of addressing them, impoliteness, impropriety, a rude and bossy tone) are palpable. ${ }^{6}$

A more robust and inquisitive press concerned with stories of interest to ordinary Yugoslavs emerged at the same time that layers of bureaucracy across the country were objectively expanding, and citizens were losing their patience in their dealings with them. Dejan Jović, in his detailed study of the ideological impetus underscoring Yugoslavia's disintegration-the "withering away" of the state-details how the 1976 restructuring with the Law on Associated Labor saw the economy devolve "into various small units, all becoming more and more 'autarkic.' Instead of enabling direct democracy within 'selfmanagement' [the party-state], became more bureaucratic than ever" (Jović 2009, 83). Instead of the "debureaucratization of society," a sea of new regulations was issued to support and explain new structures" (Jović 2009, 143).

With the economic crisis of the post-Tito era and the response by federal authorities disproportionally affecting workers in production and squeezing living standards (Magaš 1993, 
190), the context was set for increasingly populist representations of divisions between "us and them." In the view of most workers, bureaucrats were overpaid, nonproductive, white-collar administrative workers and lower-level managers (režija) who did not directly create wealth. In the 1980s, however, the categorization broadened to include functionaries, initially municipal and regional officials but later also high officials (Vladisavljević 2008, 173).

The antibureaucratic theme was not just a resonant aspect of Yugoslav political discourse but also fed into popular culture. Marko Grdešić $(2016,775)$ provides a cultural argument to explain the interlocking of Serbian nationalism and Leninist socialism (and the relative weakness of liberalism) in the context of the antibureaucratic revolution drawing on Veljko Vujačić's (2003) work on ideological convergence between orthodox communism and extreme nationalists in late socialist Serbia. In addition to this convincing argument, I suggest that there is a broader cultural dimension to "antibureaucratism" in Yugoslavia that is not specific to Serbia and was visible across the country during the early 1980s. The 1980s witnessed what S.P. Ramet (1985a, 3) has termed an "apocalypse culture," an introverted anomie and "quest for meanings" that brought into question the "fundamental political and social values of the society." Perhaps in response to an ever more cynical citizenry, the party-state launched various ad hoc measures to tackle corruption and the abuse of power in the immediate post-Tito era. Rather than shore up the League of Communists, however, the tepid results damaged the party's reputation further (Archer 2015).

A series of widely reported public scandals reached a peak in late 1987, when the Agrokomerc food-processing system in Velika Kladuša, northwest Bosnia Herzegovina, collapsed under the weight of a scheme of unsecured promissory notes (Andjelic 2003, 57-61; Woodward 1995, 295), an event that further mainstreamed the notion of corrupt bureaucrats abusing positions of political power. Publicized instances of corruption like Agrokomerc created a direct link in the minds of many Yugoslavs between the machinations occurring in their workplaces and the republic and federal political nomenklatura. For example, in the wake of the Agrokomerc scandal, a Tanjug news agency interview with Branko Mikulić, then president of the Federal Executive Council, addressed the danger of federal (Yugoslav) "centralism, statism and bureaucratisms" (Novi list, September 8, 1987, 3).

In the media of late socialist Yugoslavia, many municipal bureaucracies were described as "heartless" and accused of improperly interpreting regulations and hampering the possibilities for residents to access permits in order to build suitable housing (Archer 2018, 144-145). Sympathetic newspaper reports would side with ordinary citizens, acknowledging the unfair and uneven application of rules. Zagreb daily Vjesnik (October 26, 1980), for example, announced in a headline that "life does not wait for spatial plans." On April 4, 1987, regional newspapers Novi list (Rijeka) and Glas Istre (Pula) ran as their headline "theme of the week" on concerns about bureaucratic procedures on the island of Pag relating to housing construction, "The Cry against Bureaucratic Arbitrariness."7 The municipal assembly was accused by journalists of "bureaucratic violence" by incorrectly enforcing building regulations that prevented individuals from legally building on their own land for four years.

\section{Workers in Northwest Croatia in the 1980s}

Politically, Croatia has been termed by observers as "the sullen republic" between 1974 and 1989 (Irvine 2007, 168). Its political culture tended to be more inert and conservative than those of Slovenia and Serbia, which had witnessed the development of increasingly lively and autonomous subcultures and social movements, as well as combative political groupings in the League of Communists by the 1980s. Croatian socialist conservatism was largely a consequence of the removal of nationalist and liberal cadres and party members following the Croatian Spring in the early 1970s. However, despite the region's designation as "sullen," workers in Croatia were as politically engaged as were their counterparts elsewhere in Yugoslavia. While workers were underrepresented in power structures throughout Yugoslavia (Obradović and Dunn 1978), their concerns and perspectives were sometimes critically expressed in the party-state. For example, in November 1981, a worker member of the Central Committee of the League of Communists of Croatia, Pavao 
Bežan from Duga Resa reportedly spoke up at a Central Committee meeting, attracting attention with his critique of the party:

People expected more concrete decisions from the Croatian Central Committee meeting in November; those responsible for failures, errors, misdemeanors should be named; there were too many bureaucratic bodies, and too many which did not do their job ... The workers do not the feeling that the party is on top of things... . It has let things slip ... There should be more openness, no behind the scenes manipulation. ${ }^{8}$

Perhaps influenced by the dramatic activities of the Solidarity trade union in Poland, in the early 1980s, domestic and foreign observers took the "mood of the workers" seriously. For example, documents from the British embassy in Yugoslavia from 1981 repeatedly mention the challenge of gauging the elusive "mood of the workers." The disposition of Yugoslav workers was discussed in a telephone conversation between the British ambassador and Vladimir Bakarić, a member of the Yugoslav presidency, in October 1981. In the same month, the British ambassador met with the chairperson of the Croatian Trade Union Federation in Zagreb and received a report on the 21 strikes that had occurred in Croatia between July and September 1981. ${ }^{9}$ Initially, labor mobilizations were more numerous in Croatia (and Slovenia) than they were in less developed parts of Yugoslavia (Vladisavljević 2008, 111). In 1987, the most high-profile strike in Socialist Yugoslavia to date took place in the Labin mine in Istria (Kuzmanić 1988). ${ }^{10}$ Another notable strike saw workers from the Borovo plant near Vukovar march to the Federal Parliament building in Belgrade in July 1988 (Ivčić, Nekić, and Račić 2014; Cvek, Ivčić, and Račić 2015).

A growing literature on Yugoslav "worlds of work" takes the agency of workers seriously and engages with theoretical and methodological advances in the field of global labor history that it couples with rigorous empirical research (Bonfiglioli 2015, 2018; Calori and Jurkat 2018; Cvek, Ivčić, and Račić 2015; Musić 2016; Rutar 2014, 2015; Schult 2017). Rather than revealing "the syndrome of radical egalitarianism” as per Josip Županov (1983), whereby Yugoslav workers allegedly claimed "they could not pay me as little as I can work" (Jović 2009, 163) an analysis of the crisis of the early 1980 s at the level of the self-managing workplace reveals that workers, far from being a homogenous grouping, had a range of motivations, concerns, and interests (Archer and Musić 2017).

While cynical representations and dissatisfaction were tangible, this intersected and coexisted with a meaningful commitment to labor and the workplace; a "structure of feeling" (Williams 1978, 131-132; see also Bonfiglioli 2019) and sociality shaped by factory work. The factory was often considered as a "second home" and the center of one's community. The sometimes ambivalent state-society relations thus cannot be reduced to jealousy, begrudgery, or "equality in poverty" on the part of workers (Jović 2009, 162-163) as a close reading of sources from the workplace and local communities reveals. Presuming that elites and blue-collar workers entered into a pact underwritten by laziness and deceit risks reproducing what Alexei Yurchak $(2005,9)$ critiques as the "underlying assumption that socialism was based on a complex web of immoralities." It also overlooks the various formal and informal mechanisms that workers and other actors engaged in as a means to address social conflict in Yugoslavia. For example, in 1971, a report by Radio Free Europe on a strike by Rijeka dockworkers noted that the conflicting sides entered into negotiations in a businesslike manner and media reports were accurate and measured in tone. In fact, what made this labor mobilization notable, the report opined, was that it was unremarkable and procedural (Antic 1971).

\section{“How Much More Will Individuals Take over Social Property?" Representations of Worker Dissatisfaction in Northwest Croatia}

Alison Stenning $(2005,987)$ writes that the centrality of workers in state-socialist societies "tended to encourage extreme representations of working-class communities-ranging from the heroic to the ridiculous." Yugoslavia was no exception in this regard, with the representations of workers and 
factory work shifting between inherent reverence and deep skepticism, the contrasts between which were brought into even greater relief throughout the 1980s as the incomes and symbolic capital of industrial workers declined. Workers themselves were concerned with a wide range of "negative phenomena" in the factory, relating both to the economic performance of the collective and to work ethic. In documents from workplaces like company periodicals, detailed commentary and biting cartoons and aphorisms rued a sharp drop in living standards workers in production; the ever-growing divisions between blue-collar and white-collar workers; housing shortages; the proliferation of bureaucracy, careerism, corruption, and the theft of social property; and the waning of a socialist work ethic on the part of both blue-collar and white-collar workers, as evident in the increase in shirking, absenteeism, and sick leave. Such themes were in broad public circulation in industrial centers like Rijeka, Labin, and Pula.

In early 1977, a couple of years in advance of the economic crisis that would envelop the country, a sailor, Živko Mataija, wrote an open letter to the workplace periodical of Jugolinija. He claimed to have witnessed captains and first officers "privatizing social property" (in other words, stealing) on board Jugolinija ships. The ship's inventory would be removed and sold off to wheelers and dealers while in global ports like Alexandria, Suez, Singapore, and Hong Kong, and a cut given to the crew. Mataija stated that it was not his wish to write a letter due to "bad intentions" or "because of a run-in with someone." Rather, his aims were "in accordance with societal norms" and represented a "call to working people of Jugolinija to fight for a better tomorrow." 11

The editor of the Jugolinija periodical-a glossy but serious publication with a print run of around 7,000 copies-supported Mataija's viewpoint and suggested that his letter was very apt; Jugolinija found itself in economic difficulties, and the previous year had been the most difficult in its 30-year history. As in many discussions published in workplace periodicals, a direct connection was made between theft from the company and the economic difficulties the company found itself in. Thus, the editor endorsed the call of Mataija, encouraged other Jugolinija workers to be equally conscientious, and committed to reporting on each suggestion and comment that might further this goal.

Mataija's intervention, however, does not appear to have had the desired effect of reining in theft and recouping losses for the company. Examining Jugolinija workplace periodicals in the decade after his letter was published, along with documents from other work organizations in the regions of Kvarner and Istria and the Rijeka branch of the League of Communists of Croatia, it is evident that economic and political crisis in Yugoslavia also had an impact on this comparatively wealthy corner of northwest Croatia. By 1987, over a quarter of the workforce in northwest Croatia worked at regional industrial heavyweights that were running losses. ${ }^{12}$ Strikes were increasing in number and intensity. The League of Communists and major industries were attempting ad hoc reforms in a response to public discontent and calls for the removal of compromised functionaries. Similarly, theft from workplaces, the phenomenon that Mataija had decried, remained a perennial problem. Theft took the forms both of the casual pilfering of items that were then transported out of the factory perimeter (for example in the case of Uljanik shipyard, often by small boat) ${ }^{13}$ and more elaborate schemes involving individuals in positions of authority, such as the senior kitchen workers on a Jugolinija ship who sold off much of the food for the crew while at port and then proceeded to serve inferior, cheaper food while at sea, even making the crew fish for their dinner when supplies dwindled. ${ }^{14}$

The theme of bureaucracy, closely connected to theft and the abuse of one's position, was also a regular feature in company periodicals and documents, particular in the less formal cartoons and images accompanying texts and in letters and complaints from individual workers, where criticism was particularly pronounced (Archer and Musić 2017, 55). The bureaucracy was directly linked to the abuse of power, inhibiting business and contributing to growing social inequalities and other pathologies. For example, in a 1983 edition of Jugolinija's periodical, in the section "Questions without Answers" a subheadline asked, "What Does 'Vulnerable' Mean?" The comment detailed how free holidays had been taken up by 170 Jugolinija workers, only 80 of whom were 
sailors (blue-collar workers) while the rest were in administrative positions. "If we are not mistaken, the [social welfare] institution of a free holiday is earmarked for workers in the most vulnerable positions with weak material status ... We ask ourselves, are so many administrative workers really 'vulnerable' or are they a 'vulnerable' category?"15

Yugoslav workplace periodicals and proto-tabloids consistently presented in text and images workers being taken advantage of or in some way negatively affected by the actions of white-collar workers. A 1983 cartoon in Jugolinija's periodical suggests that blue-collar workers were silenced by bureaucrats: a booming white-collar worker has his voice amplified by five separate microphones, but the voice of the dejected blue-collar worker, speaking unamplified, goes unheard (figure 1). Similar imagery positioning workers against bureaucrats can be seen in Pula's Uljanik shipyard. In one telling image on the back cover of the company periodical, blue-collar workers are shown in a tug-of-war with portly, suited men. The activity is rigged in favor of the bureaucrats, however: the rope is tied to a pole behind them. ${ }^{16}$ Austerity measures are presented as a burden placed on the shoulders of blue-collar workers, not affecting white-collar workers to the same extent. A cartoon in the periodical of the Brodokomerc trade and tourism firm depicts a uniformed blue-collar worker buckling under the weight of the heavy end of a tree trunk called "intervention measures" that he is carrying, while behind him, an administrative worker in a suit holds a much smaller part of the burden (figure 2).

During the course of the 1980s, excessive bureaucracy in the workplace began to be more forcefully linked to criticisms of bureaucracy at the municipal, republican, and federal levels. This was a point of resonance not only in Serbia and Montenegro but also among Croatian workers. Sometimes bureaucrats were represented as foteljaši ("armchair hoggers"), occupying positions of power solely due to the fringe benefits they received. They were presented in worker periodicals and the popular press as rotating between positions and behaving arrogantly, not in the interests of the workers, the work collective, or the broader society (figure 3). On other occasions, bureaucracy was represented as holding back business and inhibiting economic activity. A 1984 edition of the Uljanik periodical depicts a large ship called "Yugo-administration" that a small boat called "business," rowed by a frantic worker, is unsuccessfully attempting to tow (figure 4). The bloated

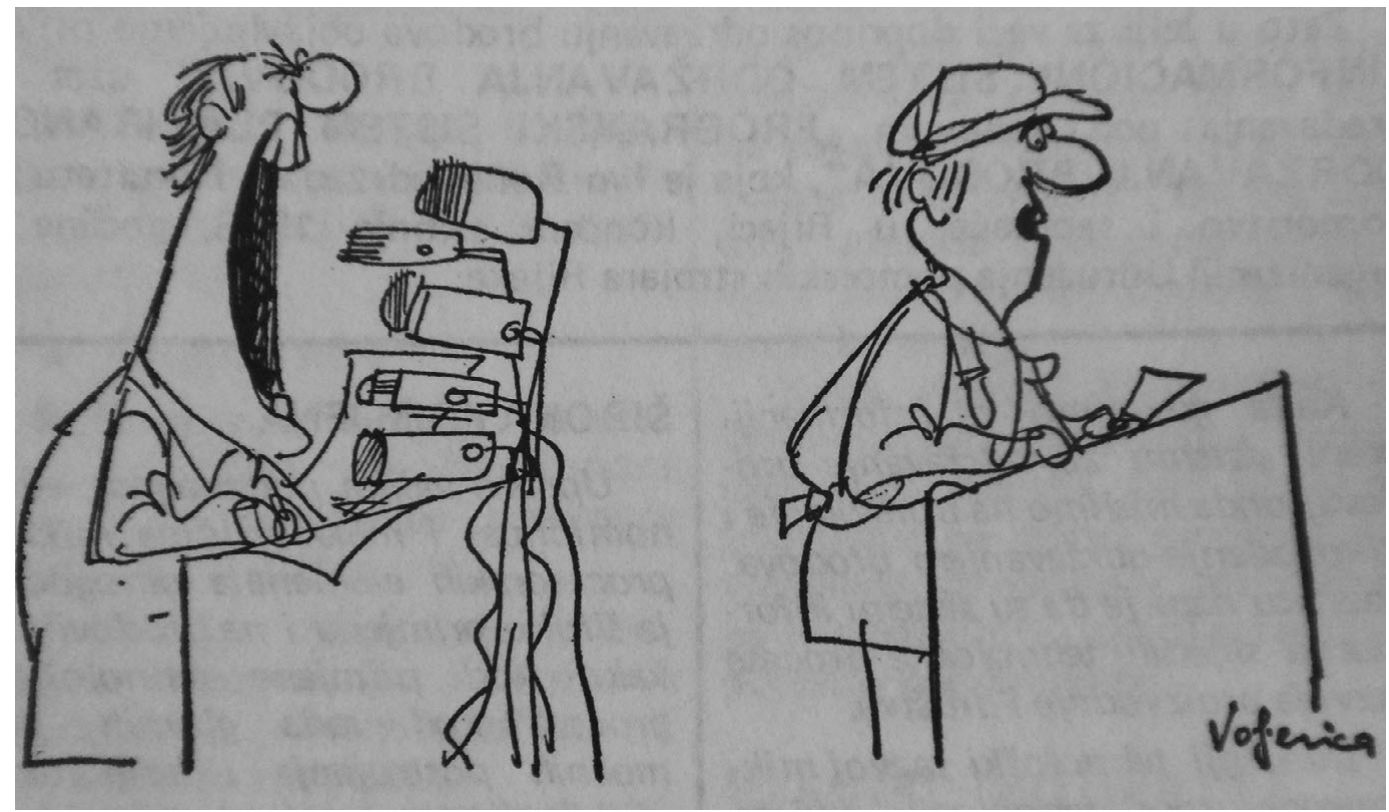

Figure 1. Cartoon from Jugolinija (List radne organizacije Jugolinija, Rijeka, no. 104, 1983, 17). 


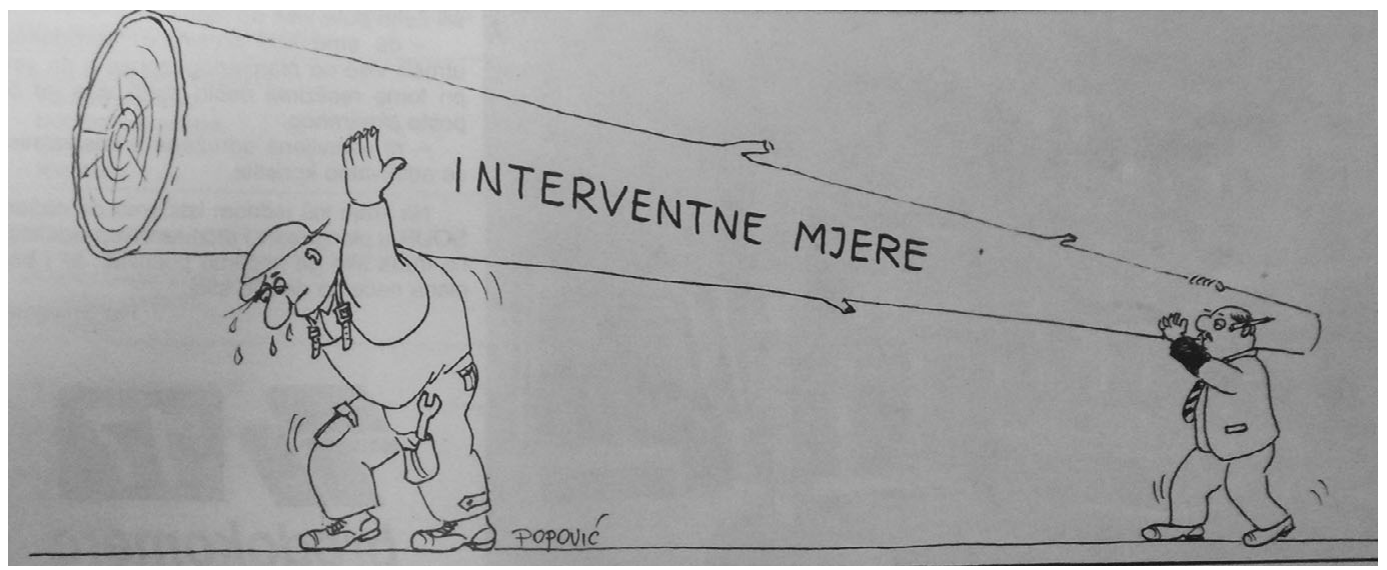

Figure 2. Detail from the back cover of Brodokomerc (Vjesnik SOUR-a Brodokomerc, no. 65-66, 1987).

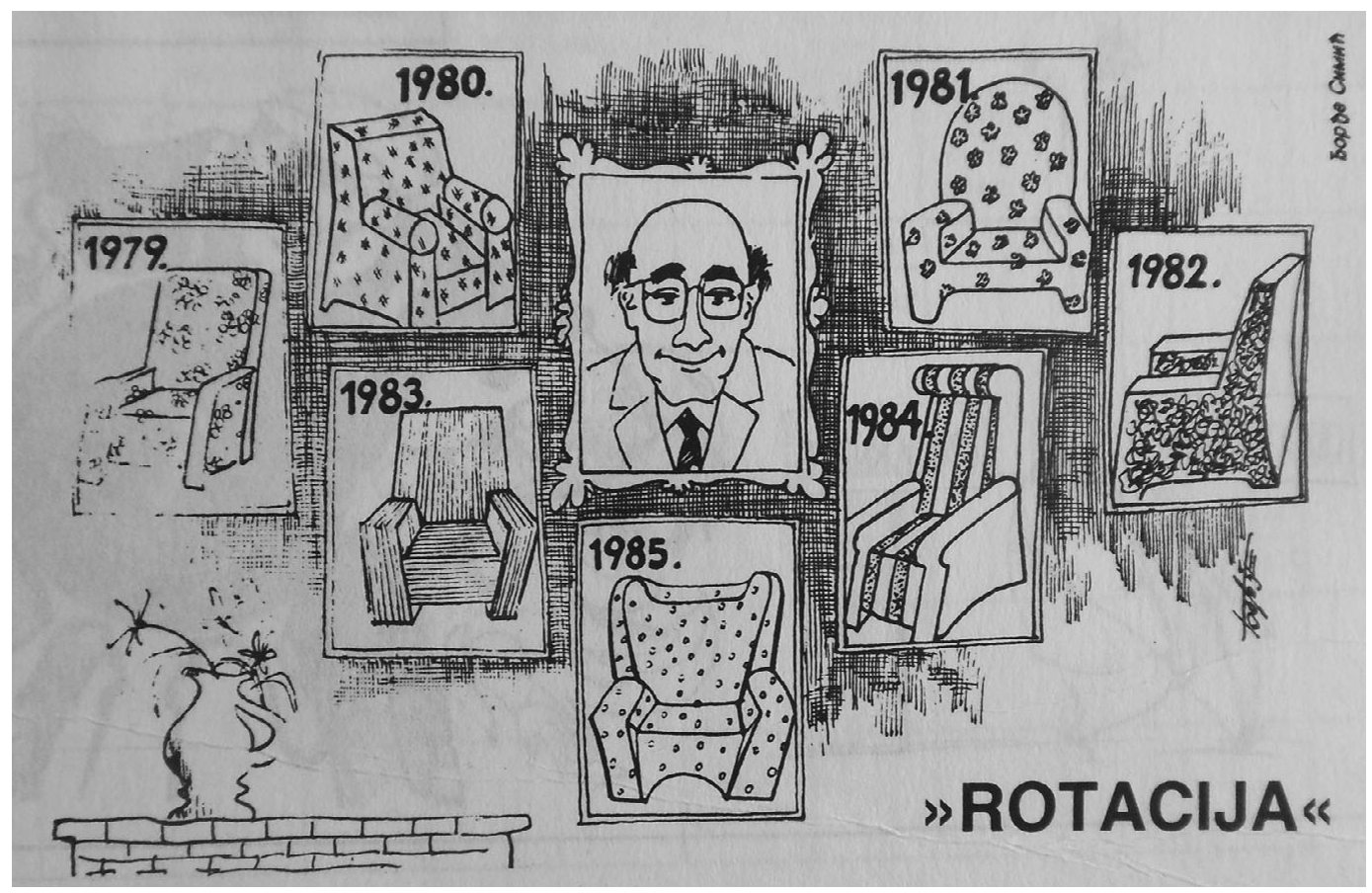

Figure 3. "Rotation.” Cartoon from Jugolinija (List radne organizacije Jugolinija, Rijeka, no. 106, 1984, 44).

administration is unambiguously presented as a hindrance to profitability. Thus, antibureaucratic sentiment could be deployed from an economically liberal position as well as from a more familiar blue-collar, redistributive one.

When speaking about their workplaces, many blue-collar workers, in addition to stressing the burden of low wages and disappointment at federal measures further reducing their pay, also criticized the administration and management of their companies. A transport worker in Rijeka port, Branko Bitunjac, stated that he did not believe "that such a high number of administrative staff exist in any other developed country." ${ }^{17}$ Not only was the proliferation of bureaucratic positions called into question, but so was their moral standing. A survey of Rijeka port workers about morality 


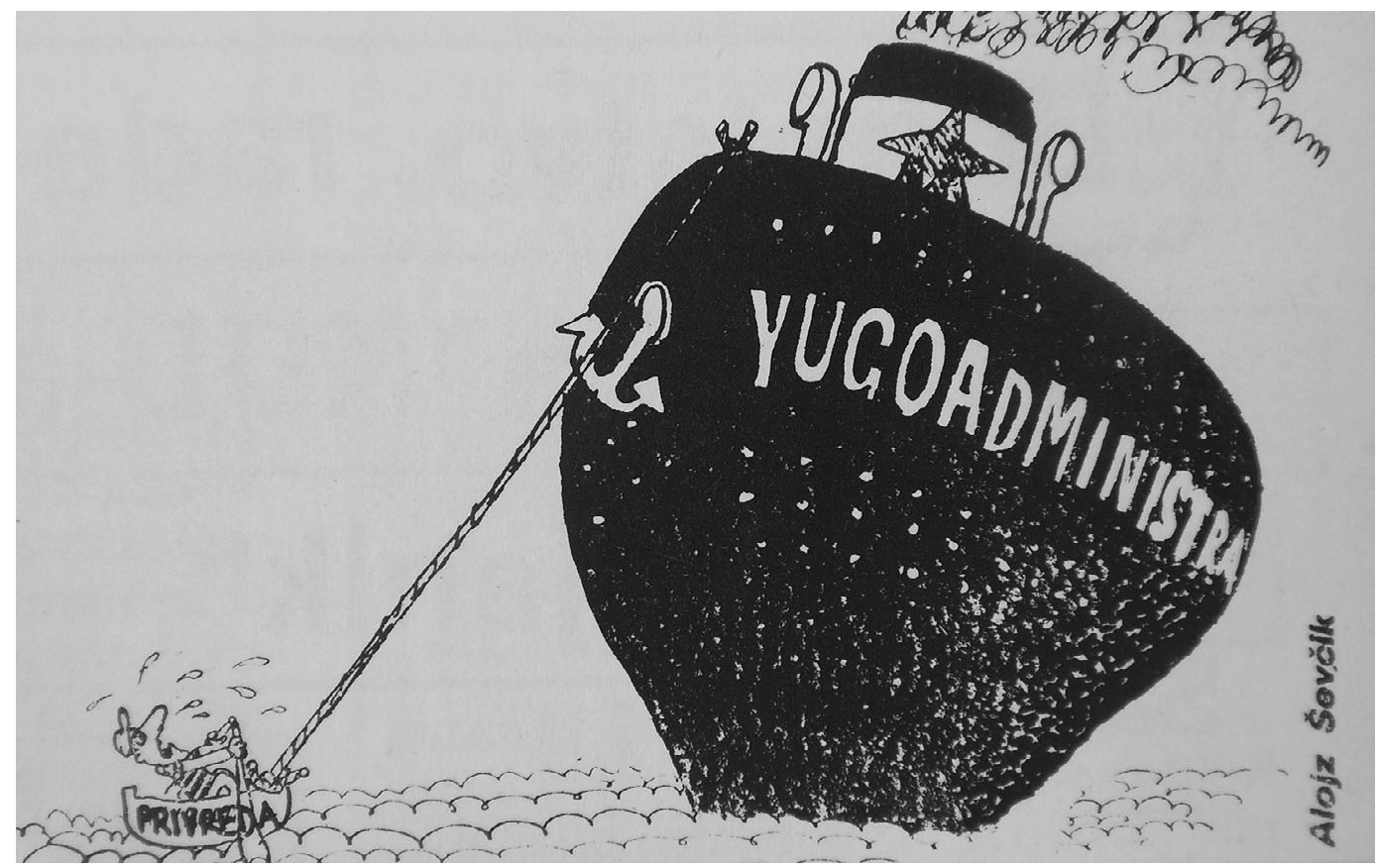

Figure 4. "Yugo-administration." Detail from the back cover of Uljanik (Uljanik: Mjesečnik SOUR-a brodograđevna industrija, no. $38,1984,5)$.

and ethics undertaken in the weeks after the Agrokomerc scandal made its first shockwaves gave voice to many workers who were dissatisfied and confused about the role of their workplaces in the affair. In particular, they were concerned about the actions of directors and managers who may have knowingly colluded with Fikret Abdić and the Agromkomerc system or were guilty by association.

Ivan Obajdin, a worker in the tool storage unit of Rijeka Port, declared,

[a]ll of us employed in the work organization "Rijeka Port" are dissatisfied. We are dissatisfied not only because of our wages but because of all that has happened in our society and that which is happening in the port. People are simply surprised, lost, but still ready to prove that they are capable because they still wish to go to work, to work hard, to create value [through their work].

From the management at all levels it is claimed our system is excellent. However, working people whose living standard is more endangered everyday are no longer convinced. Clearly they have been tricked. I think personally that we need to make changes in cadres. The solution surely lies in better cadres, more capable and moral. ${ }^{18}$

Obajdin's colleagues expressed similar views-change was needed in management structures to reduce administration and increase output. A group of his colleagues expressed their frustration with the differentiation in treatment between blue-collar workers and management. Perhaps in no small way inspired by dominant media discourses of the period, their views corresponded to the type of populist sentiment emerging from Serbian and Montenegrin workplaces in the late 1980s:

There is much honesty among us workers. But among managers there is too little ... From the press, television, everywhere around us we see examples of the theft of social property ... Everything is put on the back of the worker. Tools get stolen, especially those expensive and quality ones. We work out in the open. During our break we cannot leave tools in the 
workplace [as they will get stolen]... . When the tools "go missing" then we workers have to pay, out of our own wages. We ask ourselves, has it ever happened that a manager ever had to take responsibility for a missing tool, or for a failed investment? Are we all equally responsible for what we do and are we judged to the same criteria? ${ }^{19}$

A human interest report from 1989, investigating how the workers of Uljanik shipyard in Pula lived, featured an interview with security guard Marijan Posavac, who expressed similar views to the Rijeka port workers. Regarding the crisis in Uljanik, Posavec stated that it was essential to immediately "reduce the enormous and unnecessary administration" not only in the shipyard but in the country more generally. He believed it was necessary to "reduce the enormous state [federal], republic and municipal apparatus," ${ }^{20}$ paralleling views emanating from Serbia that called for a recentralization of Yugoslavia, purportedly on an economic basis.

\section{From Kosovo to Agrokomerc: The Circulation of Tropes in Late Socialist Yugoslavia}

A Jugolinija cartoon showed the various problems facing the ordinary Yugoslav, who is termed a "consumer, struggling to hold up a burden of heavy rocks that include shirking, huge administration, massive meetings, negligence (javašluk), irrationality, nonproductivity, and faking (folirancija) (figure 5). The respective problems visually conflated in this cartoon were frequently presented as interlinked in workplace periodicals and the Yugoslav press.

Certain representations and themes are specific to the particular region, industrial sector, or company identity. In coastal Pula and Rijeka, for example, drawing upon nautical themes is common, as are references to the local dialect. Other representations, however, draw from a Yugoslav-wide repertoire of ideas, themes, and images. In many cases, texts and images were directly reproduced from publications of other Yugoslav republics. Some images were submitted by workers, others were composed by professional cartoonists, such as Predrag Koraksić "Corax" (Jovanović 2000). Cartoons from Titograd's Pobjeda or an article from Belgrade's Borba or management magazine Direktor might be reproduced for the local and factory press in Rijeka and Pula. In other cases a Yugoslav perspective, for example, from news agency Tanjug, would be provided.

Political histories of 1980s Yugoslavia rightly point to the polycentric or even fractured media space (Jović 2009, 41n15). Yet, a comparison of factory sources in the late 1970s and 1980s from a range of industrial sectors and diverse geographical sites-such as the garment industry in Zrenjanin, Vojvodina; the automotive sector in Maribor, Priboj (Sandžak) and Rakovica (Belgrade); metal works in Montenegro; and the shipbuilding industries and shipping companies in Bar, Montengro, and Rijeka and Pula in Croatia-points toward commonalities. Despite decentralizing impulses, there was a coherent repertoire of themes familiar to Yugoslav workers in circulation across the country. This repertoire was informed by workplace socialization and the various institutions of the party-state through which workers learned to "speak self-management" (Kotkin 1995).

An obvious source of commonalities in antibureaucratic tropes in Serbia and Croatia includes the publication of aphorisms and cynical commentary of writers like Milovan Vitezović. These were a ubiquitous item in Serbian and Montenegrin workplace periodicals throughout the 1980s and also made inroads in Croatia. ${ }^{21}$ In 1982 for example, Jugolinija's periodical ran a sarcastic passage written by Vitezović on careerists, "the hero of our era." 22 His work was frequently reproduced in company periodicals, appearing on the front cover of Uljanik's paper in $1987 .{ }^{23}$ Vitezović would later be closely associated with Milosevic's antibureaucratic revolution, allegedly coining the phrase "the happening of the people" while speaking at the largest protest meeting in Belgrade (Ušće) in November 1988 (e-Novine 2015) Prior to this, however, his maxims and aphorisms were popular across the country as part of a cynical pan-Yugoslav popular culture that predominated in the 1980s. Similar satirical quips and aphorisms by other authors abound in workplace documents. One instructive example was featured in Jugolinija's peridical; authored by "Frane," it posits, "What is 


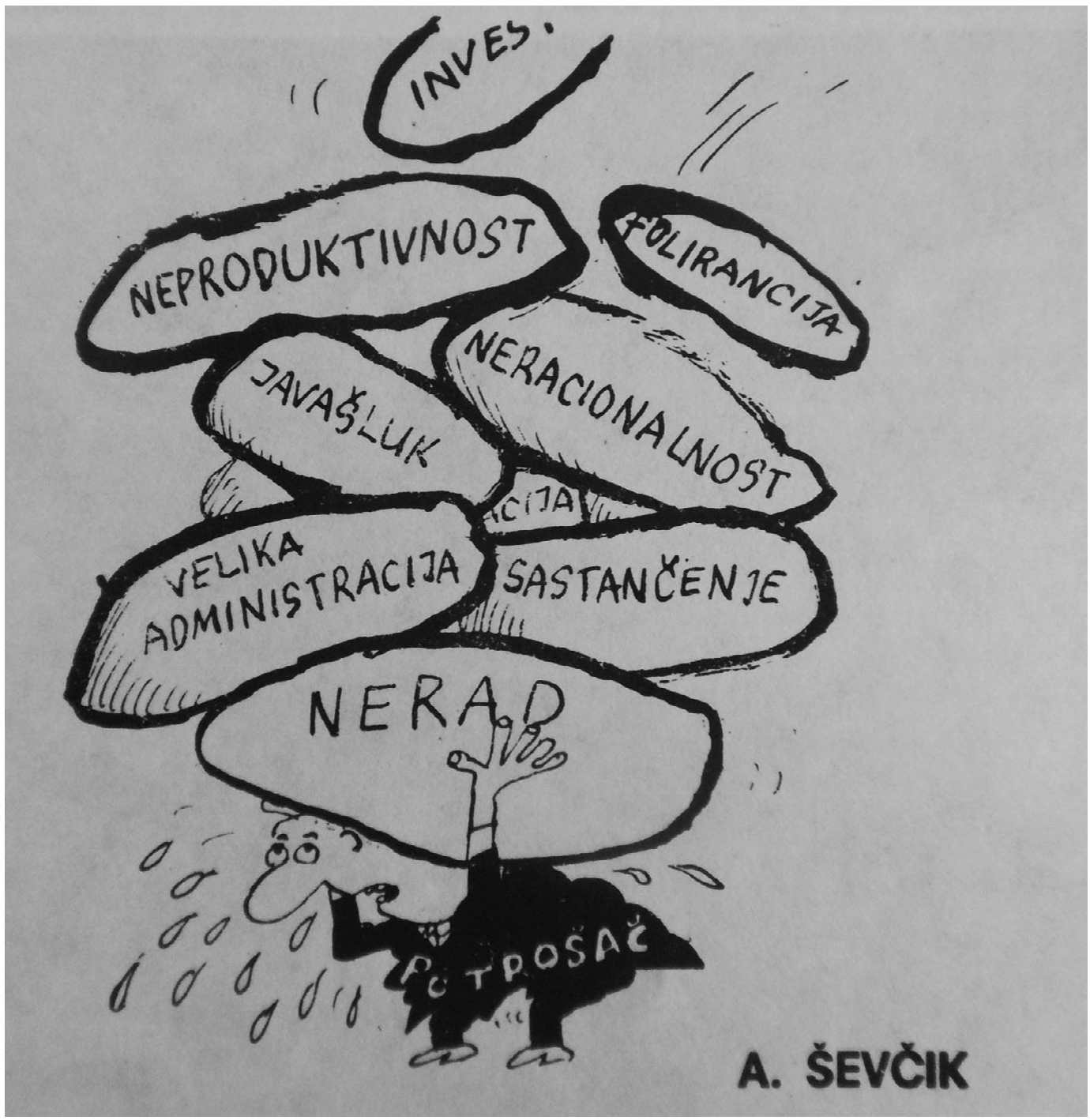

Figure 5. Burden on the Yugoslav consumer. Cartoon from Jugolinija (no. 104, 1983, 17).

the working class? The working class is a mass without a voice. It can rise if yeast is added." ${ }^{24}$ A 1987 issue of Uljanik's periodical featured the following stark comment on its back cover: "In capitalism the differences are social, but in socialism the differences are capital." ${ }^{25}$

By the mid-1980s, venerated symbols of communism were the butt of jokes in worker periodicals. Jugolinija's periodical featured a set or irreverent cartoons under the title "Marx and Us." 26 One featured Karl Marx reading a book, commenting, "You translated me well, but when will you be implementing it?" A second cartoon depicts two workers in overalls looking at a departing car (presumably with white-collar workers as passengers) commenting, "That's really not fair. He left them the capital but for us just the manifesto!" A third one features a worker snoozing in a hammock inside a hammer and sickle. Despite this widespread cynical humor and political intimacy (Klumbyte 2011) demonstrated by workplace publications and regional press regarding the deviant behavior of managers and functionaries, the sometimes lackluster work ethic of blue-collar workers and toying with fundamental symbols of communism like Karl Marx, the 
topic of nationalism and discrimination on the basis of ethnicity was not readily addressed. In documents from workplaces and local party organizations, no overt nationalist agitation is evident. Of course, one cannot draw firm conclusions from this absence. In the case of Kosovo, for example, it is clear that workplace periodicals are not useful sources to inform upon the demonstrations of 1981 and issues of interethnic relations. Although documents sent by the League of Communists of Kosovo to other republican and provincial party leaderships indicates that workers were mobilized, ${ }^{27}$ the view from workplace periodicals runs contrary. In Suva Reka rubber plant for example, a successful industry in the early 1980s for Kosovo standards, their workplace publication simply ceased in the spring of 1981, only to emerge in the summer with bombastic claims (drawn from a report by Politika ekspres) of "labor against counterrevolution." "28

In Rijeka and its environs, the issue of ethnic polarization in Kosovo was not at the forefront of inhabitants' concerns, but nevertheless the issue did become topical. In the spring of 1981, immediately after the protests of Kosovar Albanians in the autonomous province, a three-page article in Jugolinija's periodical described the "attempt at counterrevolution in Kosovo." It lumped disparate enemies of the state together, like Hoxhaists and Ballist fascists who allegedly had links to the Croatian emigre Ustashe movement. ${ }^{29}$ Reports in Novi list following the shooting of Yugoslav People's Army recruits by a Kosovo Albanian conscript in the army's Paraćin barracks in September 1987 similarly followed the official (federal) line from Belgrade, claiming that the perpetrator "shot at Yugoslavia" and linking his actions to "counterrevolution in Kosovo," describing it as a "Yugoslav problem." In early 1988 authorities in Labin investigated graffiti daubed on the walls of a cement factory calling for "Kosovo republika." ${ }^{30}$ In Rijeka a working group was formed by the League of Communists to address the problem of Kosovo and to help foster political and economic links between the city and the autonomous province. ${ }^{31}$ Not until the summer of 1988 did explicitly critical views about rising Serbian nationalism find expression; prior to this the key focus was on Albanian "irredentists." By late 1988, however, Novi list and Glas Istre dispatched two reporters, Veljko Vičević and Edo Stojčić, and a photographer, Silvano Ježina, to Kosovo, and they covered the tumultuous events of early 1989 in detail and independently of the prevailing discourse from Belgrade.

\section{The Antibureaucratic Revolution and the View from Northwest Croatia}

In Rijeka and the wider region, the last years of the 1980s saw a rise in strikes and demands that certain managers, directors and functionaries be removed from their positions. The Yugoslavia-wide scandal of the Agrokomerc food production complex had a particularly strong impact on the city, paralyzing political and economic activity during the autumn of 1987, and it led to a "noticeable shaking of confidence of a large number of people in the League of Communists and the system itself." ${ }^{\text {2 }}$ Not only was Rijeka the closest port to Velika Kladuša, but many Rijeka-based companies worked closely with Agrokomerc, and when the extent of the corruption became public knowledge it created shockwaves in socially owned enterprises in the city. A number of Rijeka's firms were implicated in illegal operations, including the Brodokomerc trade and tourism company, the local bank (Riječka poslovna banka), Brodomaterijal, Transjug, and the port facilities (RO "Luka"). ${ }^{33}$

The Agrokomerc affair damaged even further the trust that blue-collar workers had in management and functionaries, and it encouraged an outpouring of antibureaucratic sentiment in Rijeka. A September 24, 1987, meeting of management and all political and social organizations of Brodokomerc in Opatija "aroused public interest like never before" due to its association with Agrokomerc and the possibility that suspected illegal business practices in the Brodokomerc system would be confirmed. ${ }^{34}$ The front-page coverage sympathized with Agrokomerc workers, however, claiming that they "could never have guessed that their management and president of the executive board, Fikret Abdić, showing bureaucratic and technocratic arbitrariness [birokratska i tehnokratska samovolja], would alienate their self-management rights and devalue their work efforts, and not only theirs but that of the entire working class of the country, which has been inflicted a blow with far-reaching consequences." 35 
The backlash of the Agrokomerc affair provoked cadre changes. The director of Brodokomerc, for example, immediately resigned, and investigations began at all segments of the company. Jugolinija also experienced cadre turbulence in the second half of 1987, with the general director resigning before the end of his mandate, ostensibly for personal reasons. An ad hoc group was formed to investigate the "sad state of the communists in the collective" amid reports of divisions between Jugolinija workers ("Jugolinijaši”) and those close to the former director, Josip Štefan (“Štefanovci").

Despite the rather tumultuous events in workplace and replacement of cadres, the strikes and protests in Rijeka between 1987 and 1989 did not aim to provoke the same kind of fundamental change that the more organized waves of protests sought to induce in Serbia and Montenegro. Rijeka League of Communists reported that during strikes in city, workers never left the perimeter of the factory, and they were primarily concerned with low wages. ${ }^{37}$ A report in Novi list stressed that money was the "only motive" in the 16 strikes that had occurred in the first two months of 1989 in Rijeka (Novi list, February, 26-27, 1989, 5). As Serbian protests became more visibly associated with Serbian nationalist demands, Croatian communists began to guardedly express concerns about interethnic relations and nationalism in their own republic. While local and regional industrial disputes and the expression of workers' grievances occurring in Rijeka continued to be reported on widely in the factory and local press, a more cynical attitude regarding the aims and means of Serbian protesters began to be expressed as the antibureaucratic revolution gained traction in the summer of 1988.

On August 8, 1988, a comment by young Rijeka based journalist Branko Mijić appeared in the daily Novi list. Referring to the protests sweeping through Serbia and Montenegro during the summer, he accurately described the situation by which the cult of Tito could be (ab)used to conceal less salubrious activities:

Tito's portrait in the arms of "Zmaj" workers in front of the Yugoslav federal parliament. Tito's portrait in the arms of strikers in Maribor, on the road from Borovo to Belgrade, in the [Croatian] parliament in the arms of "Vartilen" workers ... Tito's portrait all the more often is at the front of masses of the dissatisfied, at strikes, protest gatherings, trips and public meetings $[$ zborovi] ...

$[\mathrm{H}]$ owever, in the background of the displays of Tito's picture sometimes are hiding sinister motives which give individual protesters and strikers another dimension, a totally different stamp. Because, Tito hides broken and demolished municipal buildings, physical attacks of masses on individuals like a western movie lynch scene. (Novi list, August 8, 1989, 2).

The unconditional support that had been proffered when dealing with Kosovo in the early and mid-1980s was now interspersed with concerns about interethnic relations in Croatia. During the summer of 1988, the local political organizations in Knin intervened to prevent Serb workers from holding meetings in support of Kosovo Serbs (Marijan 2016, 440). When the Kosovo miners' strike broke out in February 1989, polarizing the Yugoslav federation, this same polarization began to be remapped across Croatia, and a protest meeting in support of Kosovo Serbs was held in Knin (Marijan 2016, 441). The Croatian Trade Union Federation broke with the federal ranks and supported the Kosovo Albanian miners, opening a bank account for donations to the striking miners and their families (Novi list, March 1, 1989, 2). Objections to this were voiced by workers from Serb-inhabited areas of Croatia, including the bauxite mine in Obrovac, the Borovo rubber factory near Vukovar, and the trade union of Benkovac, which demanded that donations to the Kosovo Albanian miners immediately cease and the account be closed (Novi list, March 2, 1989, 2).

In Rijeka, the League of Communists declared that "Nationalism will not pass-In Rijeka stable interethnic relations rule" (Novi list, 3 March 1989, 5). Reports referred to Rijeka as a multinational city, a bastion of Brotherhood and Unity, and "Yugoslavia in miniature." ${ }^{3}$ According to Novi list (March 3, 1989, 5), rather than ethno-national affiliation the most important personal quality was 
"the kind of person you are, the kind of worker you are." Rather than ethnonationalism, the largest concern of Rijeka's citizens and workers was how to raise wages and improve living standards (Novi list, March 3, 1989, 5).

\section{Conclusion}

In this article, I have sought to revisit the "antibureaucratic theme" in late socialist Yugoslavia highlighting a number of reasons why it had such resonance. In Yugoslavia, state bureaucracy was presented as a legitimate object of criticism according to the underpinnings of self-managing ideology, which foresaw the eventual "withering away" of the state. Criticism of bureaucratic behavior was thus common in public life, and the specter of bureaucracy would materialize and dissipate in a range of forms. Bureaucracy at all levels of decision making in Yugoslavia, including the workplace and municipalities-institutions with which workers frequently interacted-proliferated with the decentralizing impulses of the 1970s. After political and economic restructuring with the 1976 Law on Associated Labor, workers perceived the increase in administrative positions in the factories and in local political organizations. The "empty signifier" of bureaucracy became all the more recognizable in everyday life. Following sustained economic crisis after 1979, an ever more cynical popular culture and nascent tabloid media market addressed human interest stories that included working class grievances, instances of social inequalities and elite privileges, and labor mobilizations. In doing so, worker discontent was further amplified.

An examination of documents produced in workplaces across Yugoslavia demonstrates quite a high degree of coherence regarding issues of discontent, the concerns of blue-collar workers, and typical lives of working-class communities. Thus, despite well-documented decentralizing and autarkic tendencies in political and economic life in late socialist Yugoslavia (Dević 2016; Ramet 1992), the focus of working-class discontent (and representations of it) remained remarkably similar across republican boundaries, at least until the summer of 1988. It is only at this point that local media and workplace press in the Rijeka region began to differentiate between the discontent of their own striking workforce and the more militant and transformative demands being made in Serbia and Montenegro.

The antibureaucratic revolution of 1988-1989 succeeded in harnessing both socioeconomic dissatisfaction and nationally framed grievances in a Serbian nationalist mass movement in which the strands of nationalistically framed and economically based discontent reinforced one another. Although it was Serbian nationalism that ultimately made such forceful links between national demands and social demands by keeping the people or narod at the center of discussions in simultaneously nationalist and Marxist terms, the derision of the "bureaucracy" was a staple discourse of Yugoslav socialism throughout the country and became monopolized by Serbian nationalists only throughout the course of 1988 and 1989.

Acknowledgments. The author would like to thank the editor of this section, Marko Grdešić, the other contributing authors to the section and the anonymous reviewers for their comments on earlier drafts of this article.

Financial Support. This work was supported by the Austrian Science Fund under Grant P27008 and the The Fellowship Program CAS SEE, University of Rijeka, Croatia.

Disclosure. Author has nothing to disclose.

\section{Notes}

1 For detailed discussions on using workplace periodicals as sources see Rory Archer and Goran Musić (2017) and Sven Cvek (2017).

2 List radne organizacije Jugolinija, Rijeka, br. 120, rujan 1987, str. 42-43. Please note that this and all other translations in the article are mine. 
3 Internal Situation in Yugoslavia, The Domestic Political Scene, 15.12.1981. National Archives of the United Kingdom (hereafter TNA UK), FCO 28/4642, 41.

4 SKV Predsedništvo SFRJ, Predsedništvo CKSKJ, "Mere i akcije za sprovođenje zaključka sa zajedničke sednice Predsedništva SFRJ i Predsedništva CKSKJ, održane 5. marta 1986. godine o aktuelnoj političkoj situaciji u SAP Kosovo," Arhiv Vojvodine-Novi Sad, f. 334. Pokrajinski komitet Saveza komunista Vojvodine (1920-1990), 1940-1990. k. 405, Str. pov: 4-127, 16-17.

5 Centralni komitet SKJ, Predsedništvo. Informacija o osnovnim karakteristikama idejnopolitičkog stanja u društvu i SKJ i o nastupanju građanske desnice i drugih antisocijalističkih snaga, Državni Arhiv u Rijeci (HR-DARI) 339 OK SKH RI, 1987, Opći spisi, 02 (13-441), 02/5-164/1-87.

6 "Predsedništvo CK SK Srbije, Predsedništvo SR Srbije, Političko bezbednosna situacija u SR Srbiji. Beograd, 25. novembar 1986," Arhiv Vojvodine-Novi Sad, f. 334, k. 405, 9.

7 Coincidentally, this is the same day on which Slobodan Milošević infamously declared "Nobody should dare to beat you" to a group of assembled Serbs in Kosovo Polje. The incident was not reported in the regional press.

8 Internal Situation in Yugoslavia. “The Workers' View,” 08.12.1981. TNA UK, FCO 28/4642, 45.

9 Internal Situation in Yugoslavia. "Call by HM Ambassador, Belgrade, on Dr. Vladimir Bakarić [...]," 26.10.1981. TNA UK, FCO 28/4642, 11; "Vijeće saveza sindikata Hrvatske, Pregled obustava rada u SR Hrvatskoj u vremenu od 1. srpnja do 30. rujna 1981. godine, TNA UK, FCO 28/4642, 1-10.

10 See also, Izvještaj o obustvi rada u Istarskim ugljenokopima "Raša"-Labin, OK SKH Labin, 01.12.1987, Državni Arhiv u Rijeci, HR-DARI-339 OK SKH RI, 1987, Opći spisi, 02 (13-441), $02-226 / 87$.

11 List radne organizacije Jugolinija, Rijeka, br. 81, siječanj-ožujak 1977, 22.

12 Pregled gubitka OOUR-a u Zajednici općine Rijeka za razdoblje I-1X 1987. godine, 4. prošir. sjed. MOK SKH Rijeka, 17.11.1987, Državni Arhiv u Rijeci, HR-DARI-793, k. MOK RI 48. See also Novi list September 3, 1987, 2.

13 Uljanik: Mjesečnik SOUR-a brodograđevna industrija, br. 98, veljača 1989, 14.

14 Uljanik: Mjesečnik SOUR-a brodograđevna industrija, br. 119, lipanj 1987, 28.

15 List radne organizacije Jugolinija, Rijeka, br. 104, srpanj-rujan 1983, 17.

16 Uljanik: Mjesečnik SOUR-a brodogradevna industrija, br. 88, 04. travanj 1988, back cover.

17 Vjesnik RO Luka, br. 210, travanj 1987, 8.

18 Vjesnik RO Luka, br. 215, listopad 1987, 6-7.

19 Vjesnik RO Luka, br. 215, listopad 1987, 6-7.

20 Uljanik: Mjesečnik SOUR-a brodograđevna industrija, br. 98, veljača 1989, 14.

21 For example, "Aforizmi," Srbijateks: Informativni list trgovačke radne organizacije "Srbijatekst" Beograd. br. 32, mart 1984, 7; "Aforizmi," Srbijateks: Informativni list trgovačke radne organizacije "Srbijatekst Beograd. br. 38-39, decembar 1984, 9.

22 List radne organizacije Jugolinija, Rijeka, br. 98, siječanj-ožujak 1982, 27

23 Uljanik: Mjesečnik SOUR-a brodograđevna industrija, br. 82, 5. listopad 1987.

24 (Radnička klasa je masa bez glasa. Može i da se digne, ako se doda "kvasa") List radne organizacije Jugolinija, Rijeka, br.120, rujan 1987, 42.

25 Momčilo Mihajlović, Uljanik: Mjesečnik SOUR-a brodograđevna industrija, 4 rujan 1987, back cover.

26 List radne organizacije Jugolinija, Rijeka, br. 106, siječanj-ožujak 1984, 44.

27 Regular communication from the League of Communists of Kosovo in spring 1981 to other republican and provincial League of Communists expressed worry about the involvement of Albanian workers in the demonstrations and describes their mobilization in cities around Kosovo. (Arhiv Vojvodine-Novi Sad, f. 334. k. 387, Str. Pov., 41-70).

28 "Uz mašine u odbrani," Ballkan: Gazetë e fabrikës së shiritave trans dhe të rrypave trapezë të gomës "Ballkan" Suva reka, br. 73-81, 4.

29 List radne organizacije Jugolinija, Rijeka, br. 96, srpanj-rujan 1981, 2-4. 
30 Informacija o mjesečnoj aktivnosti MOK SKH Rijeka za veljaču 1988.g., 14.03.1988, Državni Arhiv u Rijeci, HR-DARI-339 OK SKH RI 1988 P2, 02-151/88, 4.

31 Teze za rad radne grupe OK SKH Rijeka za praćenje ostvarivanja zaključaka 9. sjednice CK SKJ o Kosovu, 26.01.1988, Državni Arhiv u Rijeci, HR-DARI-339 OK SKH RI 1988 P2, 02-70/1-88.

32 Stavovi komiteta za ONO i DSZ ZO Rijeka u vezi sigurnosno-političkog stanja na području ZOR-a, 5.10.1987, Državni Arhiv u Rijeci, HR-DARI-793, k. MOK RI 53, Br. Pov. 012-31/1-87.

33 Vjesnik SOUR-a Brodokomerc, br. 65-66, listopad-studeni, 1987.

34 Vjesnik SOUR-a Brodokomerc, br. 65-66, listopad-studeni, 1987, 2.

35 Vjesnik SOUR-a Brodokomerc, br. 65-66, listopad-studeni, 1987, 1.

36 List radne organizacije Jugolinija, Rijeka, br. 121, prosinac 1987, 15.

37 Josip Kukuljan: Udovno izlaganje na sjednici Predsjedništva MOK SKH Rijeka, 16. rujna 1988. godine pod točkom "Aktualna ekonomsko-socijalna i političko-sigurnosna situacija i zadaci SK,” Državni Arhiv u Rijeci, HR-DARI-339 OK SKH RI, 1988, Opći spisi, 02 (205-399), MOK, 16.IX.88, 10.

38 Report from OK SKH Rijeka sent to CK SKH, 14.01.1987, Državni Arhiv u Rijeci, HR-DARI-339 OK SKH RI, 07-36/1-87, 2.

\section{References}

Abram, Marco. 2018. “Integrating Rijeka into Socialist Yugoslavia: The Politics of National Identity and the New City's Image (1947-1955).” Nationalities Papers 46 (1): 69-85.

Andjelic, Neven. 2003. Bosnia-Herzegovina: The End of a Legacy. London: Frank Cass.

Andrejevich, Milan. 1988a. "Ethic Unrest Continues," Situation Report, Yugoslavia SR/8, September 23, Radio Free Europe/ Radio Liberty, 7-10. http://storage.osaarchivum.org/low/9a/cf/9acfd12b-8aa2-4f1c-addc-0751c67811de_l.pdf. (Accessed December 20, 2017.)

Andrejevich, Milan. 1988b. “Workers Strike and March in Belgrade.” Situation Report, Yugoslavia SR/9, October 11, Radio Free Europe/Radio Liberty, 19-21. http://storage.osaarchivum.org/low/df/a0/dfa06996-70df-4ef3-b6b2-0f2c551d0786_l.pdf. (Accessed December 20, 2017.)

Andrejevich, Milan. 1988c. "Protests Go beyond Nationalism." Situation Report, Yugoslavia SR/9, October 11, Radio Free Europe/Radio Liberty, 23-26. http://storage.osaarchivum.org/low/df/a0/dfa06996-70df-4ef3-b6b2-0f2c551d0786_l.pdf. (Accessed 20 December 2017.)

Antic, Zdenko. 1971. “Dockers' Strike Successful in Yugoslav Port of Rijeka.” Yugoslavia: Labor, June 16. Radio Free Europe Research, http://catalog.osaarchivum.org/catalog/osa:6b9c33cf-aa04-4f1a-b963-082475403cf0. (Accessed December 20, 2017.)

Archer, Rory. 2015. "Imaš kuću—vrati stan: Housing Inequalities, Socialist Morality and Discontent in 1980s Yugoslavia." Godišnjak za društvenu istoriju/Annual of Social History 20 (3): 119-139

Archer, Rory. 2018. “The Moral Economy of Home Construction in Late Socialist Yugoslavia." History and Anthropology 29 (2): 141-162.

Archer, Rory, and Goran Musić. 2017. “Approaching the Socialist Factory and Its Workforce: Considerations from Fieldwork in (Former) Yugoslavia.” Labor History 58 (1): 44-66.

Bonfiglioli, Chiara. 2019. Women and Industry in the Balkans: The Rise and Fall of the Yugoslav Textile Sector. London: I. B. Tauris.

Bonfiglioli, Chiara. 2015. "Gendered Citizenship in the Global European Periphery: Textile Workers in Post-Yugoslav States." Women's Studies International Forum 49: 57-65.

Calori, Anna, and Kathrin Jurkat. 2018. “'I'm Both a Worker and a Shareholder.' Workers' Narratives and Property Transformations in Postsocialist Bosnia-Herzegovina and Serbia.” Südosteuropa 65 (4): 654-678.

Cvek, Sven. 2017. "Class and Culture in Yugoslav Factory Newspapers." In The Cultural Life of Capitalism in Yugoslavia: (Post) Socialism and Its Other, edited by Dijana Jelača, Maša Kolanović, and Danijela Lugarić, 101-120. Cham: Palgrave Macmillan.

Cvek, Sven, Snježana Ivčić, and Jasna Račić. 2015. “Jugoslavensko radništvo u tranziciji: “Borovo” 1989.” Politička misao: Časopis za politologiju 52 (2): 7-34.

Dević, Ana. 2016. "What Nationalism Has Buried: Yugoslav Social Scientists on the Crisis, Grassroots Powerlessness and Yugoslavism." In Social Inequalities and Discontent in Yugoslav Socialism, edited by Rory Archer, Igor Duda, and Paul Stubbs, 21-37. Abingdon: Routledge.

e-Novine. 2015. "Vesti iz prošlosti: Govor Slobodana Miloševića na Ušću.” June 26. http://www.e-novine.com/srbija/srbija-tema/ 122430-Govor-Slobodana-Miloevia.html. (Accessed December 20, 2017.)

Fočo, Salih. 1989. Štrajk između iluzije i zbilje. Belgrade: Radnička štampa. 
Grdešić, Marko. 2016. “Serbia’s Anti-Bureaucratic Revolution as Manipulation? A Cultural Alternative to the Elite-Centric Approach." Comparative Studies in Society and History 58 (3): 774-803.

Grdešić, Marko. 2019. "Looking Back at Milošević’s Antibureaucratic Revolution: What Do Ordinary Participants Now Think of Their Involvement?” Nationalities Papers 47 (4): 537-544.

Irvine, Jill. 2007. “The Croatian Spring and the Dissolution of Yugoslavia.” In State Collapse in South-Eastern Europe: New Perspectives on Yugoslavia's Disintegration, edited by Lenard J. Cohen and Jasna Dragović-Soso, 149-178. West Lafayette: Purdue University Press.

Ivčić, Snježana, Martina Nekić, and Jasna Račić 2014. “'Čiji smo mi ovdje u Slavoniji?’ Štrajk radnika Borova 1988. u kontekstu mjera štednje i uspona nacionalizma u SFRJ.” Diskrepancija: Studentski časopis za društveno-humanističke teme 13 (19): 6-23.

Jovanović, Goran. 2000. “The Yugoslav War through Cartoons.” In Neighbors at War: Anthropological Perspectives on Yugoslav Ethnicity, Culture, and History, edited by Joel M. Halpern and David A. Kideckel, 255-288. University Park: Pennsylvania State University Press.

Jović, Dejan. 2009. Yugoslavia: A State that Withered Away. West Lafayette: Purdue University Press.

Klumbytè, Neringa. 2011. "Political Intimacy: Power, Laughter, and Coexistence in Late Soviet Lithuania." East European Politics and Societies 25 (4): 658-677.

Kotkin, Stephen. 1995. Magnetic Mountain: Stalinism as a Civilization. Berkley: University of California Press.

Kuzmanić, Tonči. 1988. Labinski štrajk: paradigma začetka konca. Ljubljana: Univerzitetna konferenca ZSMS.

Lekić, Bojana, Zoran Pavić, and Slaviša Lekić, eds. 2009. Antibirokratska revolucija (1987-1989). Belgrade: Službeni glasnik.

Magaš, Branka. 1993. The Destruction of Yugoslavia: Tracing the Break-Up 1980-1989. London: Verso.

Marijan, Davor. 2016. “Događanja naroda' u Kninu 1989. godine-slom jugoslavenske ustavne konstrukcije u hrvatskoj” Radovi Zavoda za povijesne znanosti HAZU u Zadru, 58: 439-467.

Musić, Goran. 2016. “They Came as Workers and Left as Serbs': The Role of Rakovica’s Blue-Collar Workers in Serbian Social Mobilizations of the Late 1980s." In Social Inequalities and Discontent in Yugoslav Socialism, edited by Rory Archer, Igor Duda, and Paul Stubbs, 132-154. Abingdon, UK: Routledge.

Obradović, Josip, and William N. Dunn. 1978. Workers, Self-Management and Organizational Power in Yugoslavia. Pittsburgh: University of Pittsburgh.

Ramet, Sabrina P. 1992. Nationalism and Federalism in Yugoslavia 1962-1991. Bloomington: Indiana University Press.

Ramet, Pedro. 1985a. “Apocalypse Culture and Social Change in Yugoslavia." In Yugoslavia in the 1980s, edited by Pedro Ramet, 3-26. Boulder: Westview Press.

Ramet, Pedro. 1985b. “The Yugoslav Press in Flux.” In Yugoslavia in the 1980s, edited by Pedro Ramet, 100-127. Boulder: Westview Press.

Patterson, Patrick Hyder. 2011. Bought and Sold: Living and Losing the Good Life in Socialist Yugoslavia. Ithaca: Cornell University Press.

Robinson, Gertrude J. 1977. Tito's Maverick Media: The Politics of Mass Communications in Yugoslavia. Urbana: University of Illinois Press.

Rutar, Sabine. 2014. “Towards a Southeast European History of Labour: Examples from Yugoslavia.” In Beyond the Balkans: Towards an Inclusive History of Southeastern Europe, edited by Sabine Rutar, 323-356. Zurich: LIT Verlag.

Rutar, Sabine. 2015. "Containing Conflict and Enforcing Consent in Titoist Yugoslavia: The 1970 Dockworkers' Strike in Koper (Slovenia)” European History Quarterly 45 (2): 275-294.

Schult, Ulrike. 2017. Zwischen Stechuhr und Selbstverwaltung: Eine Mikrogeschichte sozialer Konflikte in der jugoslawischen Fahrzeugindustrie 1965-1985. Berlin: LIT Verlag.

Sorić, Marko. 1981. Rječnik samoupravljanja. Zagreb: Informator, OOURTiskara.

Stenning, Alison. 2005. "Where is the Post-socialist Working Class? Working-Class Lives in the Spaces of (Post-)Socialism." Sociology, 39 (5): 983-999.

Sundhaussen, Holm. 2012. Jugoslawien und seine Nachfolgestaaten 1943-2011: Eine ungewöhnliche Geschichte des Gewöhnlichen. Vienna: Böhlau.

Suvin, Darko. 2011. "Bureaucracy: A Term and Concept in the Socialist Discourse about State Power (before 1941).” Politička misao: Časopis za politologiju 48 (5): 193-214.

Suvin, Darko. 2012a. "Diskurs o birokraciji i državnoj vlasti u post-revolucionarnoj Jugoslaviji 1945-1974 (I)." Politička misao: Časopis za politologiju 49 (3): 135-159.

Suvin, Darko. 2012b. “Diskurs o birokraciji i državnoj vlasti u post-revolucionarnoj Jugoslaviji 1945-1974 (II).” Politička misao: Časopis za politologiju 49 (4): 228-247.

Vladisavljević, Nebojša. 2008. Serbia's Antibureaucratic Revolution: Miloševic, the Fall of Communism and Nationalist Mobilization. Basingstoke: Palgrave Macmillan.

Vujačić, Veljko. 2003. "From Class to Nation: Left, Right, and the Ideological and Institutional Roots of Post-Communist National Socialism," East European Politics and Societies 17 (3): 359-393.

Yurchak, Alexei. 2005. Everything was Forever, until it was No More: The Last Soviet Generation. Princeton: Princeton University Press.

Williams, Raymond. 1978. Marxism and Literature. Oxford: Oxford University Press. 
580 Rory Archer

Woodward, Susan L. 1995. Socialist Unemployment: The Political Economy of Yugoslavia, 1945-1990. Princeton: Princeton University Press.

Zukin, Sharon. 1975. Beyond Marx and Tito: Theory and Practice in Yugoslav Socialism. Cambridge, UK: Cambridge University Press.

Županov, Josip. 1983. Marginalije o društvenoj krizi. Zagreb: Globus.

\section{Archival Sources}

Arhiv Vojvodine-Novi Sad, f. 334. Pokrajinski komitet Saveza komunista Vojvodine (1920-1990), 1940-1990.

Državni Arhiv u Rijeci, HR-DARI-399. Općinski komitet Saveza komunista Rijeke, 1987-1989.

Državni Arhiv u Rijeci, HR-DARI-793. Međuopćinska konferencija SKH Rijeka, 1987-1989.

The National Archives of the UK (TNA UK), FCO 28, Yugoslavia.

Cite this article: Archer, R. 2019. "Antibureaucratism" as a Yugoslav Phenomenon: The View from Northwest Croatia. Nationalities Papers 47: 562-580, doi:10.1017/nps.2018.40 